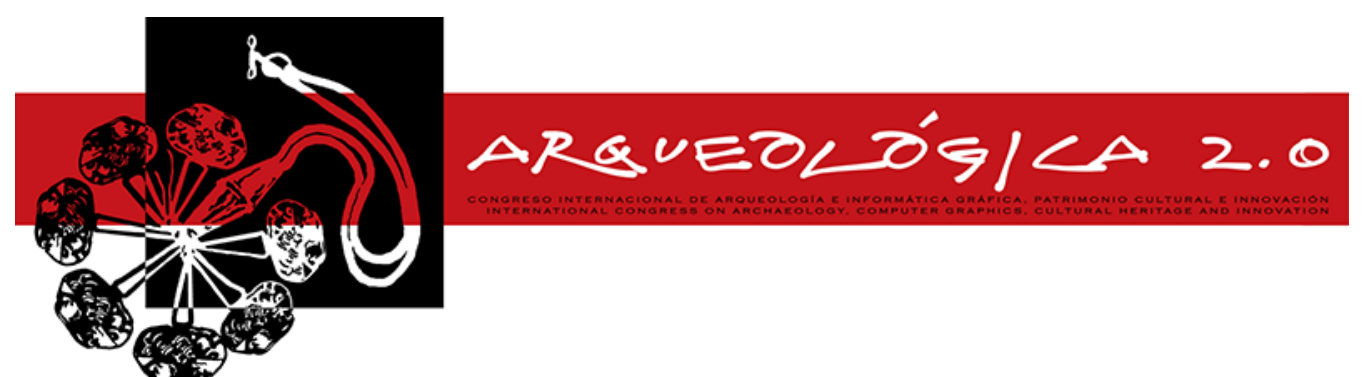

Proceedings of the $8^{\text {th }}$ International Congress on Archaeology, Computer Graphics, Cultural Heritage and Innovation

'ARQUEOLÓGICA 2.0'

in Valencia (Spain),

Sept. $5-7,2016$

DOI: http://dx.doi.org/10.4995/arqueologica8.2016.3556

Received: 01/03/2016

Accepted: 11/04/2016

\title{
CRITICAL READING OF SURVIVING STRUCTURES STARTING FROM OLD STUDIES FOR NEW RECONSTRUCTIVE PROPOSAL OF THE ROMAN THEATRE OF CATANIA
}

\author{
LECTURA CRITICA DE ESTRUCTURAS SUPERVIVIENTES A PARTIR DE ANTIGUOS ESTUDIOS PARA UNA \\ NUEVA PROPUESTA RECONSTRUCTIVA DEL TEATRO ROMANO DE CATANIA \\ Daniele Malfitana, Francesco Gabellone*, Giuseppe Cacciaguerra, Ivan Ferrari, Francesco Giuri, \\ Claudia Pantellaro
}

CNR - IBAM (Istituto per i Beni Archeologici e Monumentali), Via prov.le Monteroni, 73100 Lecce, Italy. d.malfitana@ibam.cnr.it; f.gabellone@ibam.cnr.it; g.cacciaguerra@ibam.cnr.it; i.ferrari@ibam.cnr.it; f.giuri@ibam.cnr.it; c.pantellaro@ibam.cnr.it

\begin{abstract}
:
The Graeco-Roman theatre of Catania stands in the heart of the historic centre, on the south-eastern slopes of the hill of Montevergine. The building visible today was built during the Julio-Claudian period as part of a programme that saw the rebuilding of the monument, which probably used structures and materials from the earlier Greek theatre. The work undertaken over more than fifty years, involving expropriation, demolition, excavation, and restoration, has, on the whole, made it possible to bring to light the surviving parts of the theatre, improving the comprehension of this monument, despite the fact that some sectors have been irreparably compromised.
\end{abstract}

Key words: virtual archaeology, digital archaeology, integrated technologies, 3D reconstruction, roman theatre

\section{Resumen:}

El teatro greco-romano de Catania se encuentra en el corazón del centro histórico, en las laderas del sureste de la colina de Montevergine. Visibles en la actualidad el edificio fue construido durante el período Julio-Claudia como parte de un programa que vio la reconstrucción del monumento, lo que probablemente utiliza estructuras y materiales del teatro griego anterior. El trabajo realizado durante más de cincuenta años, la participación de la expropiación, demolición, excavación y restauración, tiene, en general, hecho posible sacar a la luz las partes sobrevivientes del teatro, la mejora de la comprensión de este monumento, a pesar del hecho de que algunos sectores han sido irremediablemente comprometido.

Palabras clave: arqueología virtual, arqueología digital, tecnologías integradas, reconstrucción 3D, teatro romano

\section{The Roman theatre: research to date}

The Graeco-Roman theatre of Catania stands in the heart of the historic centre, on the south-eastern slopes of the hill of Montevergine, within an area that played a central role in the dynamics of the city's urban development. The original structure seems to date to the Greek period, as suggested by the remains of the walls in limestone blocks identified in several sectors of the monument. These elements make it possible to consider that a theatre, with a horseshoe-shaped cavea, already existed in the 4th century B.C. (Branciforti and Pagnano 2008, pp. 78-79; Branciforti 2010, pp. 192-196; Taormina 2015, p. 322; Buda 2015, p. 272).
The building visible today was built during the JulioClaudian period as part of a programme that saw the rebuilding of the monument, which probably used structures and materials from the earlier Greek theatre (Buda 2015, pp. 274-275). Between the Antonine and Severan periods, the structure was extended and underwent transformations that gave the entire complex monumental aspect (Fig. 1) (Branciforti and Pagnano 2008, Branciforti 2010, Buscemi 2012). The stage building was substantially modified by the insertion of curving exedra into the rear wall of the side doors and the enrichment of the decorative scheme, while the cavea was enlarged by the addition of the third walkway and creation of a new seating tier. The theatre was decorated with marble columns, statues, and decorative reliefs celebrating public events associated with

*Corresponding Author: Francesco Gabellone, f.gabellone@ibam.cnr.it 
mythological themes. During the final period of use, datable to around the 4th century A.D. (Branciforti and Pagnano 2008, p. 71; Branciforti 2010, pp. 198-199), the building was probably adapted for aquatic shows, with the creation of channels and systems for filling it and draining water (Buda 2015, pp. 275-277), work which also involved the repaving of the orchestra (Branciforti 2004, p. 92; Branciforti and Pagnano 2008, pp. 70-71; Branciforti 2010, pp. 198-199; Buda 2015, p. 277).

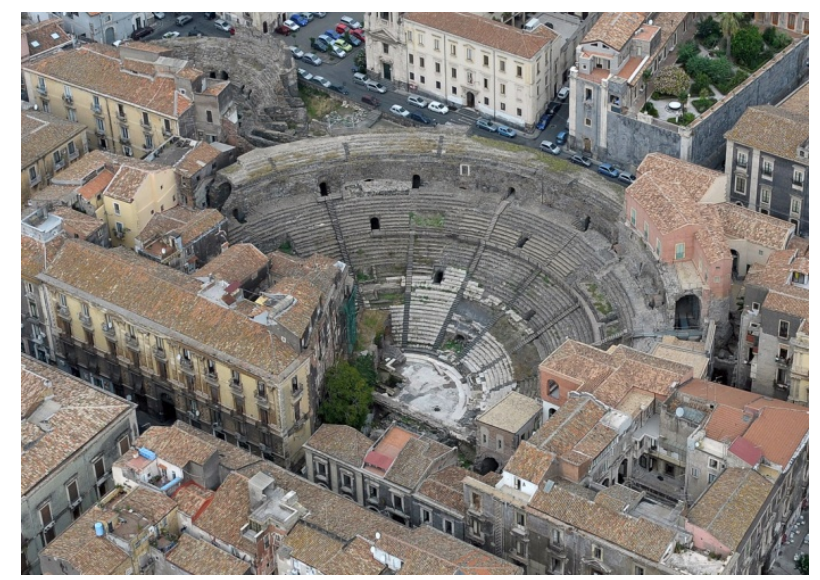

Figure 1: The monument over the actual city.

Between the 5th and 6th centuries A.D., the theatre lost its original function, as attested by the building of structures in the orchestra and gradual filling of the monument's lower part (Arcifa 2010, p. 356; Branciforti and Pagnano 2008, p. 71). From this moment onwards, the building slowly deteriorated beginning with the robbing that took place throughout the medieval period (Holm and Libertini 1925, p. 43) and then with the gradual obliteration of the ancient structures caused by the unstoppable building activity, which between the late medieval and modern periods determined the formation of a residential quarter known as "Grotte" in the theatre area (Policastro 1952, pp. 176-177; Pagnano 2010, pp. 427-438).

From the 16th century onwards many sources describe the ancient remains of theatre (Fazello 1573, pp. 93-94; Carrera 1639, pp. 83-85; De Grossis 1642, pp. 179-181). Real interest in this building began in the 18th century thanks to excavations carried out by Ignazio Paternò Castello V, Prince of Biscari (Biscari 1781, pp. 29-30). His research, begun in 1770 with the consensus of the nobles who lived in the palaces built on the Roman structure, brought to light part of the scaena and the pulpitum (Ferrara 1829, p. 275). In this phase, a large quantity of decorative elements were recovered, which once decorated the stage building, including statues of Hercules and Apollo, two Muses, a plinth with the relief of a dolphin, another Hercules, a frieze showing a gigantomachia and a large sculptured plinth (Libertini 1930, pp. 66-67; Wilson 1996, p. 158).

Subsequently, the excavations were continued by $F$. Ferrara, M. Musumeci and S. Sciuto-Patti (Ferrara 1829, p. 285; Sciuto Patti 1913, p. 312), but these were partial interventions on the cavea and in the walkways. It was only in the mid 20th century that work aimed at uncovering the theatre began. Most of the buildings built on top of it were expropriated and demolished and the exposed structures were reconstructed. In the 1960s, the architect I. Gismondi, roughly following the lines of intervention traced by G. Libertini (Libertini 1946-1947, pp. 134-141), began the work to expose the surviving parts of the cavea (Bernabò 1972-1973, p. 168). At the same time, the Archaeological Superintendency for Eastern Sicily began the excavation of the scaena and orchestra, thus promoting the first regular campaign of archaeological investigations (Rizza 1980-1981, pp. 769770). Indeed, these investigations continued in the 1980 s and 90s with the exploration of new sections of the monument, above all on the eastern side, thanks to the acquisition of the modern buildings that stood on top of it (Branciforti and Pagnano 2008, pp. 37-42). In depth excavations took place in 1998-2001, 2004-2008, and 2014-2015 (Branciforti 2006, pp. 145-154; Branciforti and Pagnano 2008; Branciforti 2010, pp. 183-209; Buda 2015, pp. 247-280; Taormina 2015, pp. 281-350). This cycle of interventions not only provided extremely interesting new evidence regarding the theatre's construction phases, but also achieved the almost complete exposure of the building, enhancing most of its structures.

The work undertaken over more than fifty years, involving expropriation, demolition, excavation, and restoration, has, on the whole, made it possible to bring to light the surviving parts of the theatre, improving the comprehension of this monument, despite the fact that some sectors have been irreparably compromised. (DM, $\mathrm{GC}, \mathrm{CP}$ )

\section{The surveying and reconstruction of the Roman theatre in Catania}

The Roman theatre of Catania is certainly one of the best-preserved examples of this type of Roman architecture, whose characteristics represent peculiarities that have still to be fully documented. The problem faced by an interpretative and reconstructive study essentially lies in the absence of accurate and up to date graphic documentation. To remedy this lacuna, it was decided to undertake a survey campaign using a laser scanner. The work in situ was set up with the aim of covering the entire complex, which due to its substantial size required the planning of a series of stations that would cover the entire external perimeter, the cavea and each individual walkway including the single flight of steps connecting them and those of the vomitoria. The coverage of all wall surfaces required the use of 39 stations, each set at a resolution of $6 \mathrm{~mm}$ on a dome of $10 \mathrm{~m}$. Due to the quantity of data in the fusion process for each individual scan in a single points cloud, (about 3 billion points - 100 giga .pts) per extrapolation of the mesh, it was necessary to subdivide the files into four parts and work on each one separately. In this way, it was possible to generate a three- dimensional model that for practical reasons had to undergo a polygonal decimation, which however facilitated the extrapolation of a series of sections then put together in technical images, which then represent the base for the process of interpreting the monument and its three-dimensional reconstruction. A first and important phase was the study and definition of the cavea's slope and exact positioning of the heights of the floor levels relating to the walkways and intermediate passageways (Figs. 2, 3 and 4). No less important was the understanding of the levels at which the spectator access points from the exterior to 
interior were positioned, and this in an urban morphological context where, precisely in the area of the Roman theatre, there are considerable differences in height. A third and just as important element was the graphic reproduction of some representative decorative architectural elements such as capitals, columns, cornices, pedestals, friezes, and statues, present within the structure, using an Image Based 3D survey with algorithms from Structure from Motion.

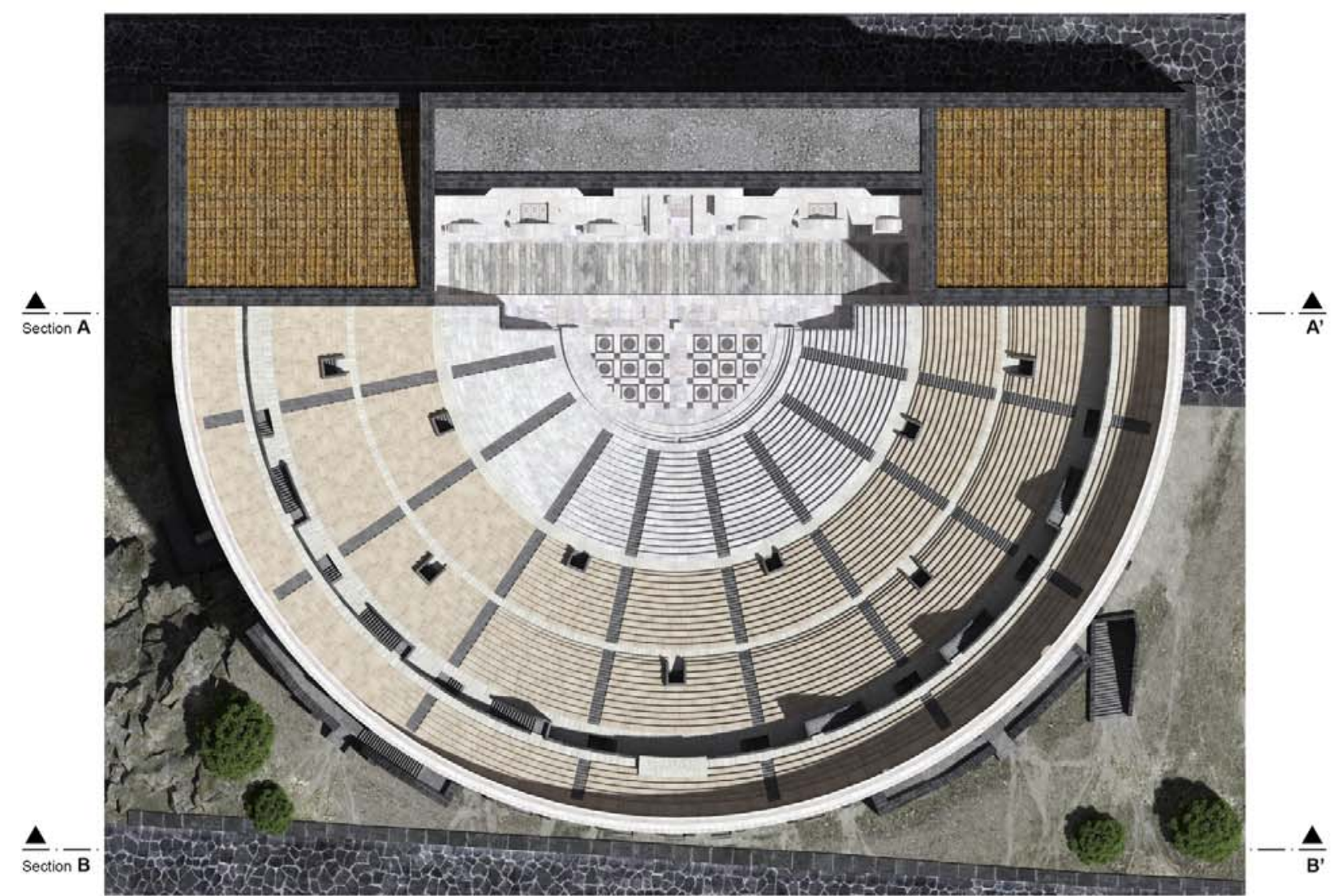

A Orthographic projection: top view

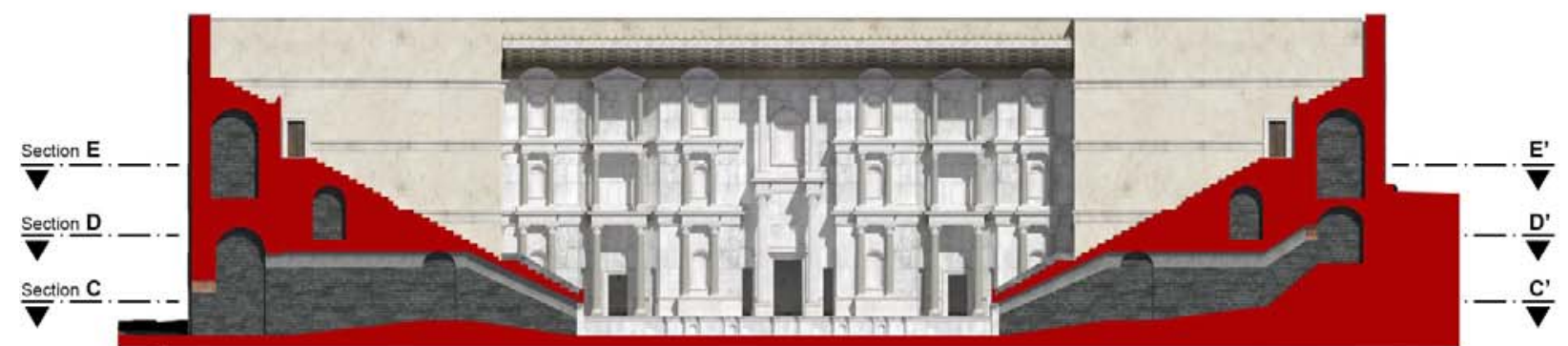

B Section A-A'

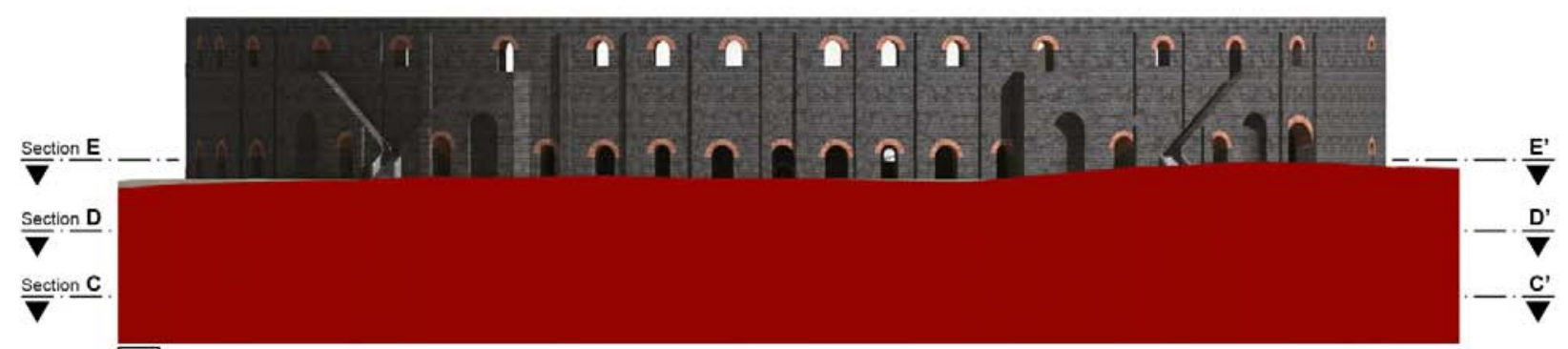

C. Section B-B'

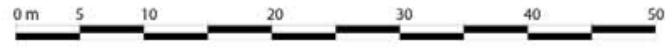

Figure 2: 3D model of the hypothetical reconstruction of the Roman theatre of Catania: Orthographic views $(A)$ and sections (B, C). 

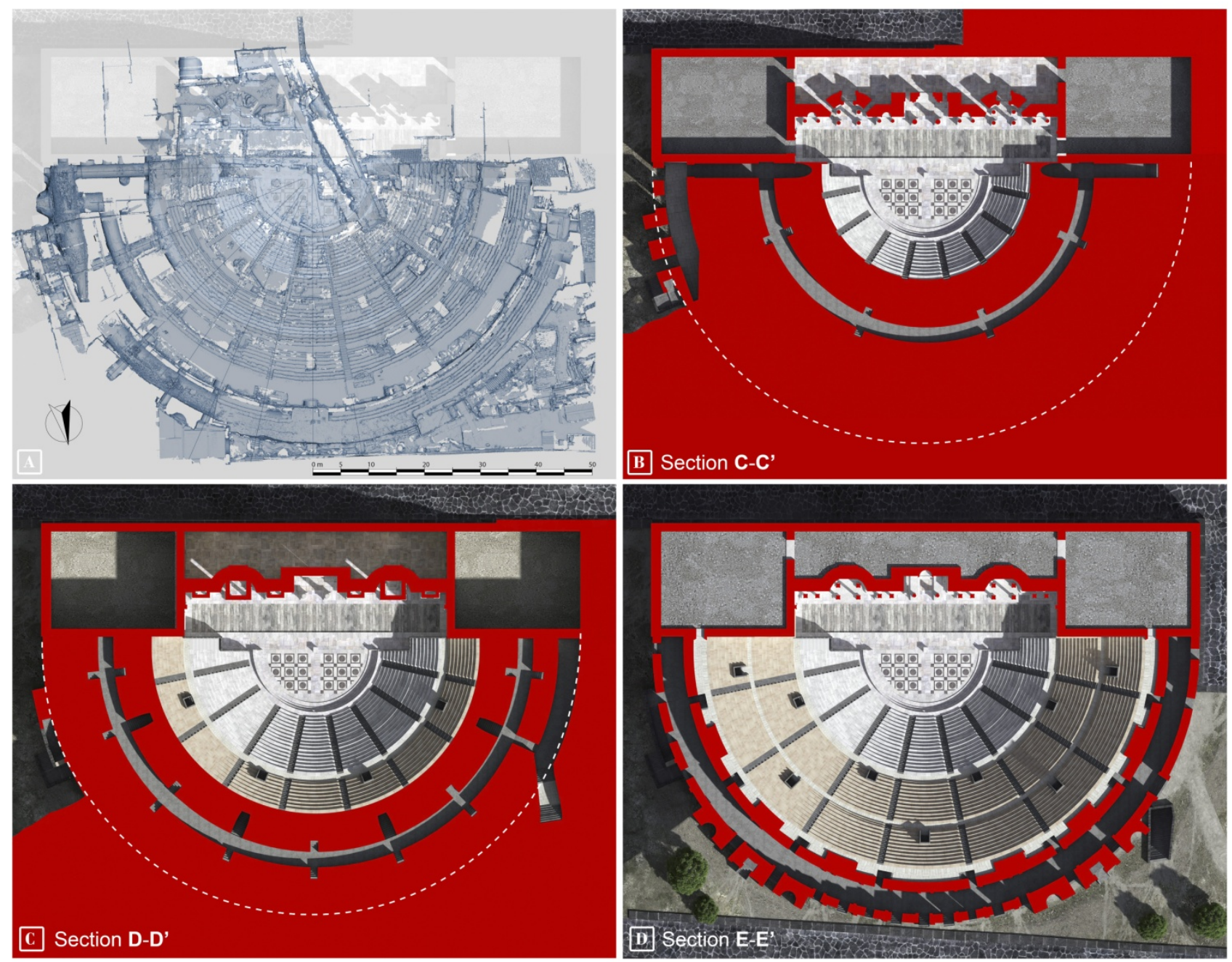

Figure 3: Orthographic views of the laser survey $(A)$ and planar sections of the Roman theatre 3D model $(B, C, D)$.

Once the metric characteristics were acquired, and the data cross-checked with the published material, it was thought opportune to link the hypothetical reconstruction to one of the monument's most interesting phases, its most monumental and richly decorated one. This construction phase has been dated to within a relatively ong period, which began in the Antonine period and probably continued until the Severan period (Pensabene 2005, p. 200; Branciforti 2010, p. 208; Buscemi 2012, p. 128). During this phase, the theatre underwent radical restoration involving the enlargement of the entire structure with the building of the third walkway and creation of a new external façade. Given the monuments' technical characteristics, with the cavea abutting the hill slope behind it, the new annular walkway could only exploit the natural support provided by the slope in its central part, making it necessary to create two different substructures that from the two sides of the scaena, supported the walkway as far as its central section. This intervention necessitated the modification of one side and a series of interventions on the other side to make the complex comply with Roman architectural canons. In fact, the rebuilding of the cavea, attested by the superimposition of the limestone blocks of the first diazoma on an earlier diazoma presumably dating to the Julio-Claudian period (Buda 2015, p. 269), was probably a direct consequence of the theatre's enlargement. The creation of a new scaenae frons, narrower than the preceding one, and a new third seating tier above the pre-existing ones, was probably part of the same restoration project (Fig. 5). Based on the archaeological data, the intervention modified the opening of the lateral doors through the creation of a curved exedra interrupted by two narrow radial corridors communicating with the rear of the stage (Branciforti and Pagnano 2008, p. 61; Branciforti 2010, p. 204). As regards the decorative elements, the repertory was notably enriched by the insertion of statues, decorative friezes, and columns in different marbles (Pensabene 2005, pp. 193-212; Branciforti and Pagnano 2008, p. 56 ), which gave the entire complex a monumental aspect.

The laser scan revealed the presence of a semicircular cavea with a maximum width of $97 \mathrm{~m}$, depth of $51 \mathrm{~m}$ and overall height that from the orchestra must presumably have reached $26 \mathrm{~m}$, with the seating tiers subdivided into nine cunei (wedge-shaped divisions) with eight radial flights of steps. Access to the seating tiers was provided by three orders of vomitoria, whose flights of steps departed from the three annular walkways that distributed the flow of spectators within the structure. Another of the problems to emerge during the reconstruction process was that relating to the points of access to the theatre, strictly related to the various external ground levels. It has emerged from the 3D study 
that most of the spectators must have entered from the north side. In fact, there was direct access from here to the external walkway via a series of arched openings each with a short flight of steps. The summa cavea could also be entered from this side thanks to the presence of two distinct masonry-built foreparts abutting the structure, each with a double flight of steps, symmetrically divergent, able to overcome a difference in height of about $8 \mathrm{~m}$. The existence of a third entrance is attested by the presence of a large flight of steps in the north-western sector, providing access to the second walkway (Fig. 6).
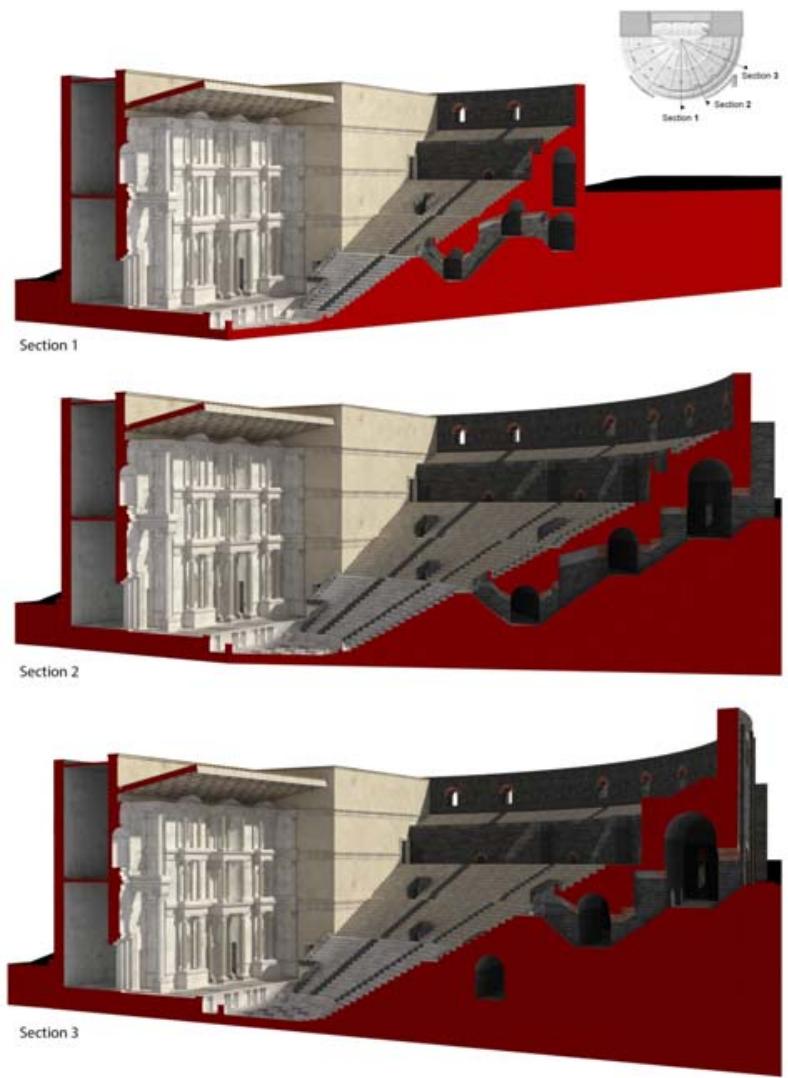

Figure 4: Vertical sections of the 3D model hypothetical reconstruction.

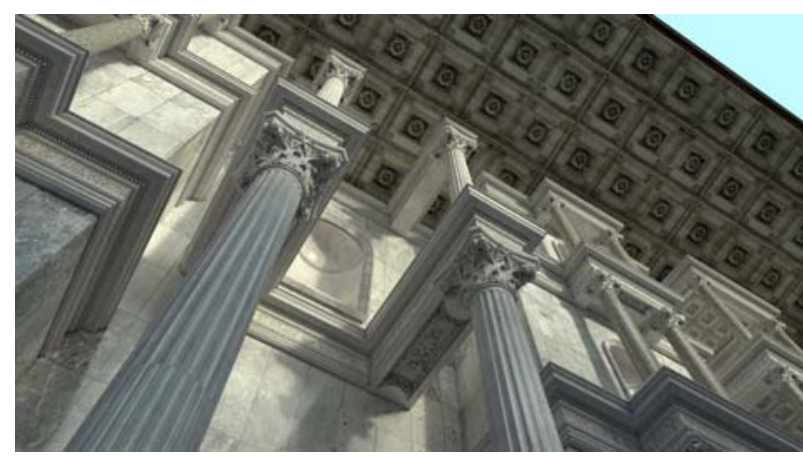

Figure 5: Detail of the scaenae frons 3D reconstruction.

There was further access to the theatre in the eastern sector, at a notably lower level, $13 \mathrm{~m}$, than those described above. The flow of spectators from the eastern part of the theatre had another external forepart available to it that covered a jump in height of about 11 $\mathrm{m}$ to lead into the third walkway. Alternatively, a number of arched passageways led directly into the so-called eastern atrium on the same level. This in turn was linked via a radial passageway directly to the eastern aditon for access to the orchestra floor, crossed in the central portion of the lower walkway.

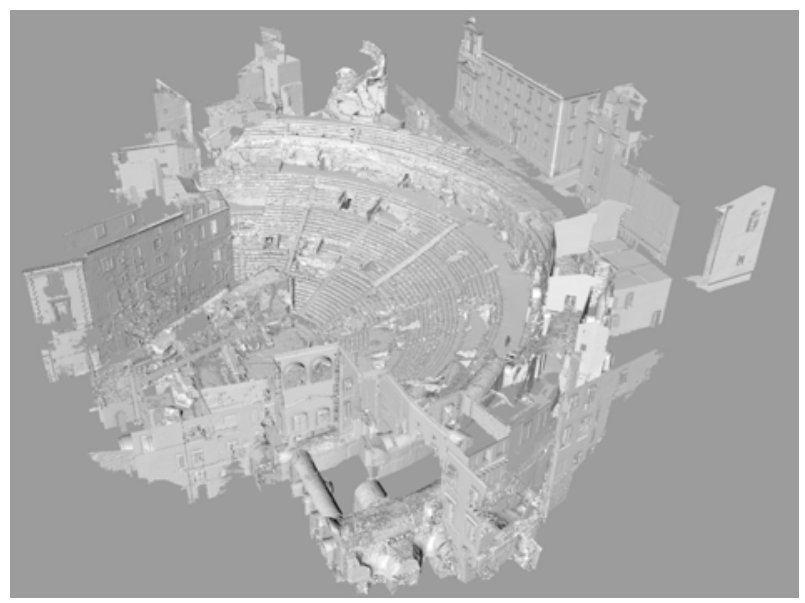

Figure 6: Laser survey of the theatre.

Particular attention was paid to the reconstruction of the stage building, of which only the eastern part is preserved, while the western side remains unexplored as an imposing $19^{\text {th }}$ century palace stands on top of it (Branciforti and Pagnano 2008, p. 56). In the proposed three-dimensional hypothesis - based on the AntonineSeveran period - the foreparts with short longitudinal flights of steps that from the orchestra led up onto the stage have been omitted as they belonged to a later phase. The orchestra has been re-proposed with its original flooring of bi-chrome marble slabs, shaped to create geometric motifs with inscribed circles inside squares. The study also included the recontextualization of the Roman theatre within the urban fabric also characterized by the presence of the Odeon, another Roman building of considerable importance whose remains are still visible in the west area of the theatre (Fig. 7). (FGa, IF, FGi)

\section{Conclusions}

This study provides an unpublished hypothetical reconstruction of the Roman theatre of Catania, aimed at the dissemination of cultural content also immediately understandable by non-experts, in an urban environment that has been modified over the centuries. The survey with Laser Scanner has been useful to rectify the weaknesses of the graphic documentation available today and has been the starting point for the development of a three-dimensional model which incorporates all the historical archaeological and architectural information available for the structure. The hypothesis proposed is the result of a study that uses direct analysis of the remains, integrated by the important contribution offered by the availability of an enhanced observation in a virtual environment. The many information gaps on archaeological and historical level has been supplemented by a comparative study with other contemporary structures. This contribution is taken as a starting point for further studies and investigations that they can better redefine the different stages of this monument, also in the light of the observations and considerations emerged following the availability of 3D models presented here. 


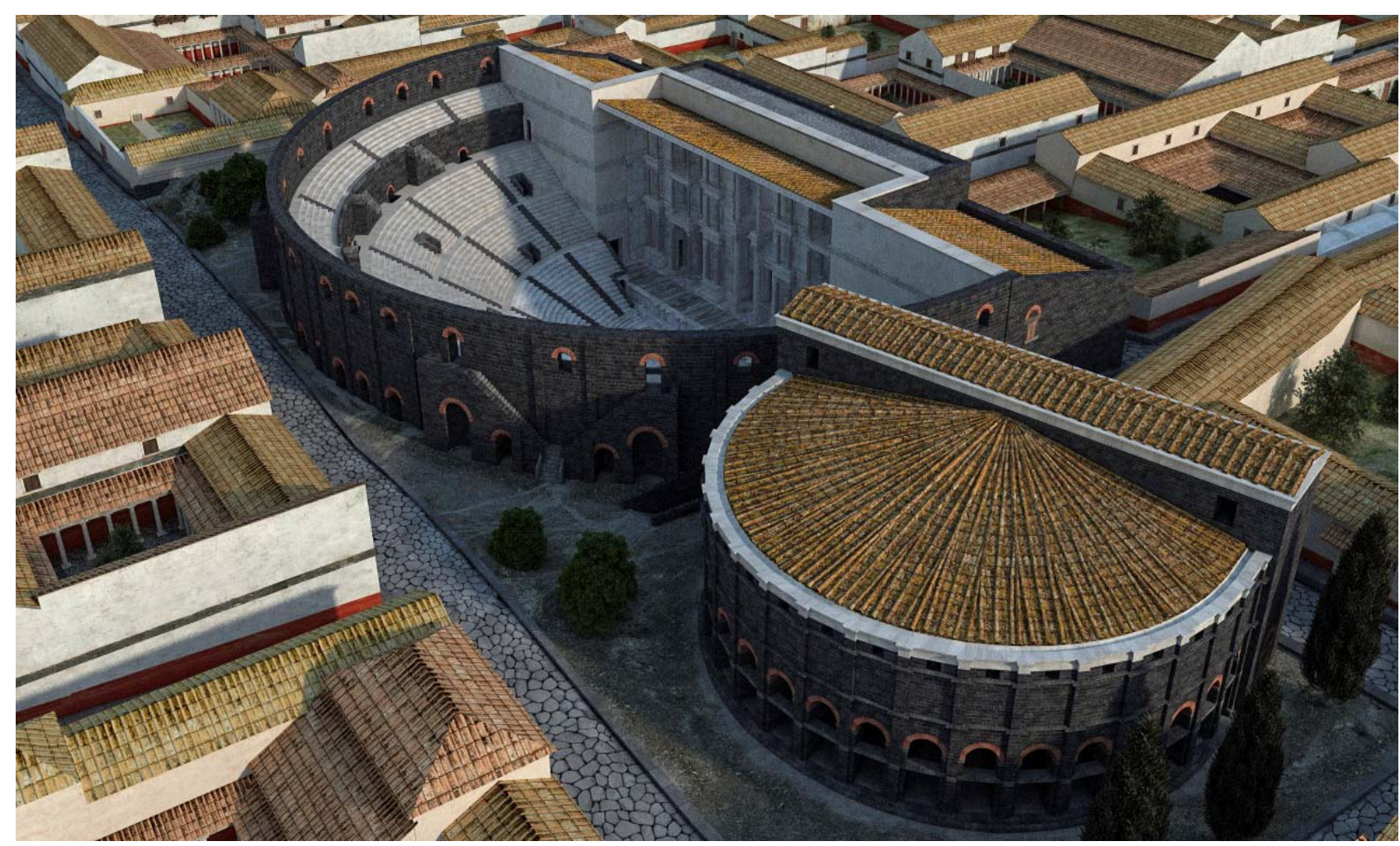

Figure 7: 3D reconstruction of the ancient Roman city of Catania: panoramic view of the theatre and Odeon.

\section{References}

ARCIFA, L., 2010. Da Agata al liotru: la costruzione dell'identità urbana nell'alto Medioevo, in: V. La Rosa, M.G. Branciforti (eds.), Tra lava e mare. Contributi all'archaiologhia di Catania, Catania 2010, pp. 355-386.

BERNABÒ, L., 1972-73. Attività della Soprintendenza alle Antichità per la Sicilia Orientale, in: Kokalos XVIII-XIX, Palermo, pp. 161-192.

BRANCIFORTI, M.G., 2004. Pavimenti in opus sectile di Catania, in: AA.VV., Apparati musivi antichi nell'area del Mediterraneo. Atti del $1^{\circ}$ Convegno Internazionale di Studi, Piazza Armerina, 9-13 Aprile 2003, Palermo, pp. 90-109.

BRANCIFORTI, M.G., 2006. II Teatro Romano di Catania, in: AA.VV., Teatri antichi nell'area del Mediterraneo. Conservazione programmata e fruizione sostenibile. Contributi analitici alla Carta del Rischio. Atti del II Convegno internazionale di studi "La materia e i segni della storia", Siracusa 13-17 ottobre 2004, Palermo, pp. 145-154.

BRANCIFORTI, M.G., 2010. Da Katane a Catina, in: M.G. Branciforti, V. La Rosa (eds.), Tra lava e mare. Contributi all'archaiologhia di Catania, Catania, pp. 183-209.

BRANCIFORTI, M.G. and PAGNANO G., 2008. II complesso archeologico del Teatro e dell'Odeon di Catania, Palermo.

BUDA, G., 2015. Teatro antico di Catania. Lavori tra il 2014 e il 2015. In: F. Nicoletti (ed.), Catania antica. Nuove prospettive di ricerca, Palermo, pp. 247-279.

BUSCEMI, F., 2012. Architettura e romanizzazione della Sicilia di età imperiale: gli edifici per spettacoli, Palermo.

CARRERA, P., 1639. Delle memorie historiche della città di Catania, Catania.

DE GROSSIS, J.B., 1642. Catanense decacordon, sive novissima sacrae Catanensis ecclesiae notitia quam tum ecclesiastica, tum secularis Catanensis politiae status universus intenta signatur, I-II, Catania.

FAZELLO, T., 1573. Le due deche dell'Historia di Sicilia (trad. R. Nannini), Venezia.

FERRARA, F., 1829. Storia di Catania fino alla fine del XVIII secolo, Catania.

GABELLONE, F., FERRARI, I. and GIURI, F., 2015. Digital restoration using Image-Based 3D models, in: Proceedings of the 1st International Conference on Metrology for Archaeology, Benevento - Italy, October 21-23, 2015, Benevento, pp. 534- 538. 
GABELLONE, F., FERRARI, I., GIURI, F. and CHIFFI M., 2015. The contribution of the 3D study for new reconstructive proposals of Lecce in Roman age, in: Proceedings of the 1st International Conference on Metrology for Archaeology, Benevento - Italy, October 21-23, Benevento, pp. 534-538.

GABELLONE, F., 2012. La trasparenza scientifica in archeologia virtuale. Una lettura critica al Principio N.7 della Carta di Siviglia, in: CASPUR CIBER Publishing SCIRES-IT, SClentific RESearch and Information Technology, vol. 2, Issue 2, pp. 99-124.

HOLM, A. and LIBERTINI G., 1925. Catania Antica, Catania.

LIBERTINI, G., 1930. II Museo Biscari. Milano-Roma.

LIBERTINI, G., 1946-1947. Due piccole sculture rinvenute nel Teatro di Catania, in: Bollettino Storico Catanese, XI-XII, pp. $134-141$

PATERNÒ, I., 1781. Viaggio per tutte le antichità della Sicilia descritto da Ignazio Paternò Principe di Biscari, Napoli.

PENSABENE, P., 2005. La decorazione architettonica del Teatro di Catania, in: R. Gigli (ed.), Megalai Nesoi. Studi dedicati a Giovanni Rizza per il suo ottantesimo compleanno, Catania, pp. 187-211.

POLICASTRO, G., 1952. Catania prima del 1693, Torino.

RIZZA, G., 1980-1981. Attività dell'Istituto di Archeologia dell'Università di Catania. Scavi e ricerche negli anni $1976-$ 1979, in: Kokalos XXVI-XXVII, II.1, pp. 746-747.

SCIUTO, S., 1913. I recenti restauri dei Monumenti antichi di Catania: I'Odeon, l'Anfiteatro romano, il Teatro greco, il Foro, in: Archivio Storico per la Sicilia Orientale, I, pp. 312-315.

TAORMINA, A., 2015. Nuove ricerche archeologiche nel teatro antico di Catania, in: F. Nicoletti (ed.), Catania antica. Nuove prospettive di ricerca, Palermo, pp. 281-349.

WILSON, R.J.A., 1996. La topografia della Catania romana, in: B. Gentili (ed.), Catania Antica. Atti del convegno della SISAC, Catania 23-24 Maggio 1992, Pisa-Roma, pp. 157-163. 